\title{
Determination of Trace Amounts of Arsenic(III) and Arsenic(V) in Drinking Water and Arsenic(III) Vapor in Air by Graphite- Furnace Atomic Absorption Spectrophotometry Using 2,3- Dimercaptopropane-1-sulfonate as a Complexing Agent
}

\author{
Chuan-Jier HsIEH, Chia-Hsin YeN and Mao-Sung KuO ${ }^{\dagger}$ \\ Department of Environmental Science, Tunghai University, Taichung 407, Taiwan, Republic of China
}

\begin{abstract}
As(III) (12.5 - $200 \mathrm{ng}$ ) in drinking water $(25 \mathrm{ml})$ reacted with 2,3-dimercaptopropane-1-sulfonate (DMPS, $0.60 \mathrm{mg})$ in ammonium acetate buffer ( $2.0 \mathrm{mmol}, \mathrm{pH} 5.5)$ and formed a complex of As(III)-DMPS. The complex was selectively retained on two Sep-Pak $\mathrm{C}_{18}$ cartridges in series, while $\mathrm{As}(\mathrm{V})$ could not be retained. Each cartridge was eluted with methanol $(2.00 \mathrm{ml})$. After addition of $\mathrm{Ni}^{2+}(2.0 \mathrm{mg})$, a portion $(20 \mu \mathrm{l})$ was introduced into a graphite cuvette and was atomized according to a temperature program. As(V) (up to $100 \mathrm{ng}$ ) in drinking water $(25 \mathrm{ml})$ was pre-reduced to As(III) with L-cysteine. The concentration of $\mathrm{As}(\mathrm{V})$ was determined by subtracting $\mathrm{As}(\mathrm{III})$ from the final total concentration of $\mathrm{As}(\mathrm{III})+\mathrm{As}(\mathrm{V})$. The method detection limits $(3 \sigma)$ for $\mathrm{As}(\mathrm{III})$ and $\mathrm{As}(\mathrm{V})$ were $0.11 \mu \mathrm{g} / \mathrm{l}$ and $0.15 \mu \mathrm{g} / \mathrm{l}$, respectively; the calibration graphs were linear up to $8.00 \mu \mathrm{g} / \mathrm{l}$ for As(III). Accuracies of $97.6-99.3 \%$ were obtained for As(III) and $\mathrm{As}(\mathrm{V})$ in drinking water with a precision within $4.0 \%$. The proposed method could be applied to the determination of As(III) vapor in air with a detection limit of $2.8 \mathrm{ng}$.
\end{abstract}

Keywords Arsenic(III), arsenic(V), drinking water, air, 2,3-dimercaptopropane-1-sulfonate, graphite-furnace atomic absorption spectrophotometry

Cumulative excess amounts of arsenic in our body may cause liver, lung, kidney, bladder or skin cancers, and chronic poisoning. ${ }^{1-3}$ In the southwest coastal region of Taiwan (Tainan and Chia-I county) ${ }^{1}$, a few residents had for more than 30 years been drinking deep groundwater containing high levels (600 - 700 $\mu \mathrm{g} / \mathrm{l})$ of arsenic compounds ${ }^{4,5}$, which caused Blackfoot Disease. Based on this phenomenon, the USEPA and Taiwan government have considered decreasing the allowable contamination levels of total arsenic in drinking water to be $2-20 \mu \mathrm{g} / 1^{6}$ and $10 \mu \mathrm{g} / \mathrm{l}$, respectively.

As(III) is considered to be more toxic than As(V), which is in turn more toxic than organic arsenics. The 8-h average permissible exposure limit for $\mathrm{As}_{2} \mathrm{O}_{3}$ in air was recommended not to exceed $0.01 \mathrm{mg} / \mathrm{m}^{3}$ of As by OSHA. ${ }^{7}$ Several methods commonly used for the determination of the amounts of arsenic species in water are flow-injection with graphite-furnace atomic absorption spectrometry (FI-GFAAS) ${ }^{8}$, or with hydride generation atomic absorption spectrometry (FIHGAAS); 910 chelating extraction and then HGAAS ${ }^{11}$, or neutron activation analysis; ${ }^{12}$ HPLC and then HGAAS $^{4}$, or HG-ICPMS; ${ }^{13}$ and ion chromatographyHG-ICPMS. ${ }^{14}$ The $\mathrm{As}_{2} \mathrm{O}_{3}$ vapor in air determined by $\mathrm{NIOSH}^{7}$ was collected on a $\mathrm{Na}_{2} \mathrm{CO}_{3}$-impregnated cellulose ester membrane. After digestion and the addition

† To whom correspondence should be addressed. of $\mathrm{Ni}^{2+}$, an aliquot $(25 \mu \mathrm{l})$ was analyzed by GFAAS. The detection limit was $0.06 \mu \mathrm{g}$ per sample and the linear range was $0.67-32 \mu \mathrm{g} / \mathrm{m}^{3}$ as As for a 400-1 sample.

2,3-Dimercaptopropane-1-sulfonate (DMPS) has been used as an antidote for mice ${ }^{15}$ and human ${ }^{16}$ poisoning with sodium arsenite, and $\mathrm{Ni}^{2+}$ has been commonly used as a chemical modifier in GFAAS ${ }^{5,17,18}$ to form a stable compound of NiAs. ${ }^{19}$ In this paper, we used DMPS as a complexing agent for As(III) in ammonium acetate buffer of $\mathrm{pH} 5.5$. The complex of As(III)-DMPS was selectively retained on Sep-Pak $\mathrm{C}_{18}$ cartridges and then concentrated in methanol; while $\mathrm{As}(\mathrm{V})$ could not be retained in this way. The As(V) was pre-reduced to As(III) with L-cysteine 9,13,20,21 $^{\text {and }}$ the total amount of $\mathrm{As}(\mathrm{III})+\mathrm{As}(\mathrm{V})$ was determined. The amount of As(V) was obtained by subtracting As(III) from $[\mathrm{As}(\mathrm{III})+\mathrm{As}(\mathrm{V})]$. Hence, trace amounts of $\mathrm{As}(\mathrm{III})$ (up to $200 \mathrm{ng}$ ) and $\mathrm{As}(\mathrm{V}$ ) (up to $100 \mathrm{ng}$ ) in drinking water $(25 \mathrm{ml})$ could be accurately determined by GFAAS. The applicability for the determination of As(III) vapor in air was also attempted.

\section{Experimental}

\section{Apparatus}

A Hitachi Z-8000 graphite-furnace atomic absorption spectrophotometer, equipped with a Zeeman back- 
ground corrector, was used for an atomic absorption measurement of arsenic at $193.7 \mathrm{~nm}$ with a slit width of $1.3 \mathrm{~nm}$. A hollow cathode lamp of As (Hitachi Co., Japan) was operated at $10 \mathrm{~mA}$. Uncoated graphite tube cuvettes (No. 180-7400, Hitachi Co., Japan) were purchased. An air sample pump (224-PCXR8, SKC Inc., PA, USA) was used for sampling air.

\section{Reagents and solutions}

Nitric acid (double distilled, Seastar Co., Canada) and hydrochloric acid (trace metal grade, Fisher Scientific Co., Canada) were used to prepare $0.2 \% \mathrm{HNO}_{3}(\mathrm{v} / \mathrm{v})$ and $0.2 \% \mathrm{HCl}(\mathrm{v} / \mathrm{v})$, respectively, with pure water (Barnstead NANOpure system). A stock standard solution of $1000 \mathrm{mg} / \mathrm{l}$ for $\mathrm{As}(\mathrm{V})\left(\mathrm{H}_{3} \mathrm{AsO}_{4}\right.$ in $\left.0.5 \mathrm{M} \mathrm{HNO}_{3}\right)$ was purchased from Merck (Germany); As(III) was prepared by dissolving $0.1320 \mathrm{~g} \mathrm{As}_{2} \mathrm{O}_{3}$ (99.995\%, Aldrich, USA) in $10 \mathrm{ml}$ of $4.0 \%(\mathrm{w} / \mathrm{v}) \mathrm{NaOH}$, acidifying with $2.0 \mathrm{ml}$ of conc. $\mathrm{HCl}$ and then diluting to 100 $\mathrm{ml}$ with pure water. Working standard solutions were diluted from the corresponding stock solution with $0.2 \% \mathrm{HNO}_{3}(\mathrm{v} / \mathrm{v})$ for $\mathrm{As}(\mathrm{V})$ or with $0.2 \% \mathrm{HCl}(\mathrm{v} / \mathrm{v})$ for As(III). In simulating the generation of As(III) vapor in air, the stock solution of $\mathrm{As}_{2} \mathrm{O}_{3}$ was diluted in methanol instead of pure water. Quality-control solutions for $\mathrm{As}(\mathrm{III})$ were prepared from $\mathrm{As}_{2} \mathrm{O}_{3}(99.999 \%$ purity, Strem Chemical Co., MA, USA); while As(V) (containing $25.0 \mathrm{mg} / \mathrm{l}$ in $10 \% \mathrm{HNO}_{3}$ ) was purchased from High Purity Standards (HPS\#290608, SC, USA). The SRM 1643d synthetic water standard (NIST, USA) contained $56.02 \pm 0.73 \mu \mathrm{g} / \mathrm{l}$ of $\mathrm{As}(\mathrm{V})$ in $0.5 \mathrm{M} \mathrm{HNO}_{3}$. A DMPS stock aqueous solution $(300 \mathrm{mg} / \mathrm{l})$ was prepared from 2,3-dimercaptopropane-1-sulfonate (95\%, Aldrich Co., USA) weekly. Ammonium acetate (GR, Merck) and acetic acid (99.99\%, Aldrich) were used to prepare an acetate buffer (2.0 M of $\mathrm{pH} 5.5)$. An aqueous solution containing $25 \mathrm{~g} / 1$ of $\mathrm{Ni}^{2+}$ was prepared from $\mathrm{Ni}\left(\mathrm{NO}_{3}\right)_{2} \cdot 6 \mathrm{H}_{2} \mathrm{O}(99.999 \%$, Aldrich). Other chemicals were of analytical reagent grade.

\section{Samples of drinking water}

Groundwater was collected from Tunghai University without any treatment; it was then treated with softening and distillation; pure water was used as test samples. Each sample was acidified to $\mathrm{pH}<2$ with conc. $\mathrm{HCl}$ for testing $\mathrm{As}(\mathrm{III})$ and with conc. $\mathrm{HNO}_{3}$ for testing $\mathrm{As}(\mathrm{V})$. One sample of Tunghai groundwater ( $\mathrm{pH}$ about 6.0) was unacidified for a comparative study.

\section{Analytical procedure for As(III) in water}

Since the optimum $\mathrm{pH}$ of this study was around $5.5,{ }^{5}$ we had to pre-adjust the $\mathrm{pHs}$ of those acidified samples to about $5.0-5.5$ by $\mathrm{NH}_{3}(\mathrm{aq})$. After the addition of the DMPS solution ( $2 \mathrm{ml}, 0.60 \mathrm{mg}$ ) and ammonium acetate buffer (2.0 mmol, pH 5.5) to unknown samples $(20 \mathrm{ml})$, or appropriate amounts (0 - $200 \mathrm{ng})$ of As(III) standard solutions, the mixture was adjusted to $25.0 \mathrm{ml}$ with pure water. The solution was mixed and allowed to stand at room temperature for about $1 \mathrm{~h}$. The As(III)-
Table 1 Suitable temperature program for As(III) in methanol solution by GFAAS

\begin{tabular}{lrc}
\hline \multicolumn{1}{c}{ Step } & Temperature $/{ }^{\circ} \mathrm{C}$ & Duration/s \\
\hline Drying & $80-120$ & 30 \\
Ashing & $150-700$ & 30 \\
& $1200-1200$ & 15 \\
Atomization $^{\mathrm{a}}$ & $2800-2800$ & 3 \\
Cleaning $^{*}$ & $2800-2800$ & 5 \\
\hline
\end{tabular}

a. Flow was stopped during atomization step.

DMPS complex was concentrated on two conditioned Sep-Pak $\mathrm{C}_{18}$ cartridges (\#51910, Waters Associates Co., MA, USA) in series by gravitational force at a flow rate of $0.6 \mathrm{ml} / \mathrm{min}$. The complex in each cartridge was eluted with methanol and adjusted to $2.00 \mathrm{ml}$. After the addition of a $125 \mu \mathrm{l}$ of $\mathrm{Ni}^{2+}$ solution $\left(2.0 \mathrm{mg} \mathrm{Ni}^{2+}\right)$, a portion $(20 \mu \mathrm{l})$ of the mixture was introduced into a graphite cuvette by a microsyringe $(50 \mu \mathrm{l}$, Hamilton Co., USA) and atomized according to a temperature program (Table 1). The peak heights in the absorbance were used for a quantitative analysis.

\section{Analytical procedure for $A s(V)$ in water}

$\mathrm{As}(\mathrm{V})$ (up to $100 \mathrm{ng}$ ) in $0.2 \% \mathrm{HNO}_{3}(\mathrm{v} / \mathrm{v}$ ) was prereduced to $\mathrm{As}(\mathrm{III})$ by adding $0.5 \mathrm{ml}$ of L-cysteine $\left(1 \%(\mathrm{w} / \mathrm{v})\right.$ in $\left.0.2 \% \mathrm{HNO}_{3}(\mathrm{v} / \mathrm{v})\right)$ and allowing the mixture to stand at room temperature for about $1 \mathrm{~h}$. After the $\mathrm{pH}$ of the solution was adjusted to $5.0-5.5$ with $\mathrm{NH}_{3}(\mathrm{aq})$, the analytical procedure for $\mathrm{As}(\mathrm{III})$ was again performed, except that five $\mathrm{C}_{18}$ cartridges in series were required. The total amount of $[\mathrm{As}(\mathrm{III})+\mathrm{As}(\mathrm{V})]$ was determined. The amount of $\mathrm{As}(\mathrm{V})$ was obtained by subtracting As(III) from $[\mathrm{As}(\mathrm{III})+\mathrm{As}(\mathrm{V})]$.

\section{Simulation for generating As(III) vapor in air}

Twenty-five milliliters of absorbing solution containing $0.60 \mathrm{mg}$ DMPS and $2.0 \mathrm{mmol}$ ammonium acetate buffer ( $\mathrm{pH} 5.5)$ were pipetted to each of two 30-ml impingers (\#1 and \#2) connected in series, as shown in our previous paper. ${ }^{22}$ A known amount (100 ng) of As(III) $\left(\mathrm{As}_{2} \mathrm{O}_{3}\right.$ in $100 \mu \mathrm{l}$ methanol solution) was introduced into a small glass chamber $(20 \mathrm{ml})$. An IR lamp (200 W, Philips Co.) was set above the chamber and turned on. During the first $10 \mathrm{~min}$, the methanol vaporized completely and was carried to the impingers by a very small air pressure ( $1-2$ air bubbles/10 s). Then, the air flow rate was increased to $250 \mathrm{ml} / \mathrm{min}$ and maintained for at least $2 \mathrm{~h}$ to carry the vaporized As(III) vapor into the absorbing solutions. The As(III)-DMPS complex in each impinger was analyzed using the procedure described above. The residue of As(III) in the chamber was extracted by adding $15 \mathrm{ml}$ of fresh absorbing solution and mixing for about $1 \mathrm{~h}$; then, the amount was measured as mentioned above. 
Table 2 Selective retention for As(III)-DMPS complex on $\mathrm{C}_{18}$ cartridges

\begin{tabular}{|c|c|c|c|c|c|c|c|c|c|c|}
\hline \multirow{2}{*}{\multicolumn{2}{|c|}{$\begin{array}{c}\text { Amount of arsenic } \\
\text { prepared/ng }\end{array}$}} & \multicolumn{8}{|c|}{ Amount of arsenic found/ng } & \\
\hline & & \multicolumn{3}{|c|}{ Without L-cysteine } & \multicolumn{6}{|c|}{ With L-cysteine } \\
\hline As(III) & $\operatorname{As}(V)$ & $\# 1$ & $\# 2$ & Total $^{\mathrm{a}}$ & $\# 1$ & $\# 2$ & $\# 3$ & $\# 4$ & $\# 5$ & Total $^{\mathrm{a}}$ \\
\hline 100 & 0 & 95.3 & 6.0 & 101.3 & 43.9 & 34.4 & 20.9 & 2.7 & 0 & 101.9 \\
\hline 50 & 50 & 50.4 & 1.0 & 51.4 & 47.2 & 34.2 & 17.6 & 2.2 & 0 & 101.2 \\
\hline 0 & 100 & 0 & 0 & 0 & 36.6 & 26.1 & 23.3 & 11.6 & 3.7 & 101.3 \\
\hline
\end{tabular}

a. The mean of triplicates.

\section{Results and Discussion}

Selective retention for As(III)-DMPS complex on $C_{18}$ cartridges

Three pairs of $25 \mathrm{ml}$ aqueous solutions were prepared containing $100 \mathrm{ng}$ of $\mathrm{As}(\mathrm{III}), 50 \mathrm{ng}$ of $\mathrm{As}(\mathrm{III})+50 \mathrm{ng}$ of $\mathrm{As}(\mathrm{V})$, and $100 \mathrm{ng}$ of $\mathrm{As}(\mathrm{V})$. In each pair, one was left untreated and one was treated with L-cysteine, respectively. Table 2 shows that when the solutions were untreated with L-cysteine, only the amounts of As(III) (in the As(III)-DMPS complex) could be retained on two $\mathrm{C}_{18}$ cartridges, while $\mathrm{As}(\mathrm{V})$ could not. When the solutions were treated with L-cysteine $\left(\mathrm{H}_{2} \mathrm{NC}(\mathrm{H})\left(\mathrm{CH}_{2} \mathrm{SH}\right) \mathrm{COOH}\right)$, some portion of $\mathrm{As}(\mathrm{III})$ might have been complexed with L-cysteine through -SH bonding besides DMPS. The complex of As(III)cysteine might have been slightly more polar than As(III)-DMPS, and four $\mathrm{C}_{18}$ cartridges were required to retain these two complexes. As(V) was pre-reduced to As(III) in the presence of L-cysteine while the L-cysteine itself might be oxidized to L-cystine $\left(\mathrm{H}_{2} \mathrm{NC}(\mathrm{H})(\mathrm{COOH}) \mathrm{CH}_{2} \mathrm{~S}-\mathrm{SCH}_{2} \mathrm{C}(\mathrm{H})(\mathrm{COOH}) \mathrm{NH}_{2}\right) .^{20,23}$ According to the distribution of the elution profile in Table 2, the polarity of the As(III)-cystine complex (through -S-S- bonding) might have been larger than that of As(III)-cysteine and As(III)-DMPS. Hence, five $\mathrm{C}_{18}$ cartridges were required to retain the complexes of As(III)-DMPS+As(III)-cystine, and the total amounts of $\mathrm{As}(\mathrm{III})+\mathrm{As}(\mathrm{V})$ could be quantitatively determined after treating with L-cysteine. In another experiment, an organic arsenic complex (dimethylarsenic acidDMPS) could not be retained on $\mathrm{C}_{18}$ cartridges either. The efficiency of the concentration procedure for 50 $200 \mathrm{ng}$ of As(III) as As(III)-DMPS complex on two Sep-Pak $\mathrm{C}_{18}$ cartridges was in the range of 98.0 $99.5 \%$, in which about $96 \%$ of As(III) was retained in the first cartridge.

\section{Temperature program}

The effect of the final ashing temperatures (1000 $1800^{\circ} \mathrm{C}$ for $10-30 \mathrm{~s}$ ) and atomization temperatures $\left(2400-2800^{\circ} \mathrm{C}\right.$ for $\left.1-5 \mathrm{~s}\right)$ on the absorbance was successively tested with $0.96 \mathrm{ng}$ As(III) in $20 \mu \mathrm{l}$ concentrated methanol solution. The results indicated that a final ashing temperature of $1200^{\circ} \mathrm{C}$ for $15 \mathrm{~s}$ and an
Amount of DMPS/mg

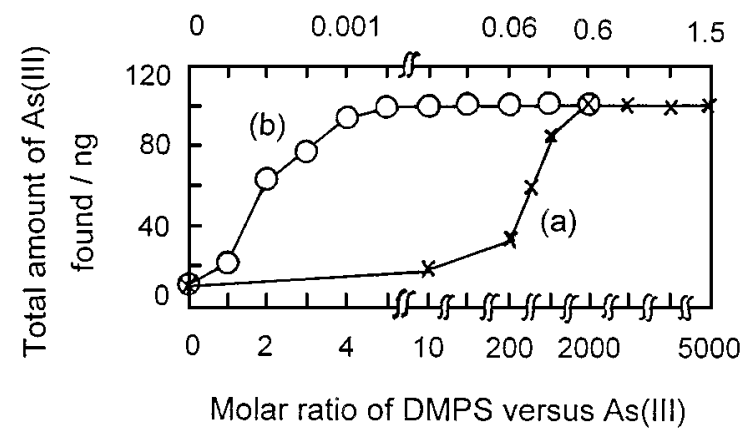

Fig. 1 Effect of DMPS on the recovery of $100 \mathrm{ng} \mathrm{As(III):} \mathrm{(a)}$ through the concentration procedure from $25-\mathrm{ml}$ aqueous solution; (b) directly prepared in methanol $(2.00 \mathrm{ml})$.

atomization temperature of $2800^{\circ} \mathrm{C}$ for $3 \mathrm{~s}$ are suitable, as tabulated in Table 1.

\section{Amount of DMPS, acetate buffer and $\mathrm{Ni}^{2+}$ used}

Two sets of experiments were performed in order to study the stoichiometric molar ratio of DMPS versus As(III). The first one was prepared in $25 \mathrm{ml}$ aqueous solutions containing $100 \mathrm{ng}$ of As(III) (i.e. $1.3 \mathrm{nmol}$ ), $2.0 \mathrm{mmol}$ ammonium acetate buffer ( $\mathrm{pH} 5.5)$, and various amounts $(0.0-1.50 \mathrm{mg}$, i.e., $0-6.6 \mu \mathrm{mol})$ of DMPS, and then going through the concentration procedure. Figure 1(a) indicates that about $100 \mathrm{ng}(100 \%$ recovery) for As(III) was found when the molar ratio of DMPS versus As(III) was in the range of 2000 - 5000 (i.e., 0.60 - $1.5 \mathrm{mg}$ of DMPS). Hence, $0.60 \mathrm{mg}$ of DMPS was selected. The second experiment was pipetting $0.16 \mathrm{mmol}$ ammonium acetate buffer (a proportional amount) and various molar ratios (0 - 2000) of DMPS versus As(III) (1.3 nmol) into small test tubes $(5.00 \mathrm{ml})$; this was then made to $2.00 \mathrm{ml}$ with methanol. After mixing and standing for about $1 \mathrm{~h}, 2.0$ $\mathrm{mg}$ of $\mathrm{Ni}^{2+}$ was added and a portion $(20 \mu \mathrm{l})$ was atomized. Figure 1(b) indicates that about $100 \%$ recovery of As(III) was obtained when the molar ratio of DMPS versus As(III) was in the range of 5 - 2000. The experimental results suggest the ratio $[\mathrm{As}(\mathrm{III})]:[\mathrm{DMPS}]=1: 5$.

The amount $(0-10.0 \mathrm{mmol})$ of ammonium acetate buffer at $\mathrm{pH} 5.5$ was varied; the results indicated that all amounts in the range $2.0-10.0 \mathrm{mmol}$ had the same 
large absorbances. Hence, $2.0 \mathrm{mmol}$ was selected. The effect of $\mathrm{Ni}^{2+}(0-50 \mu \mathrm{g})$ on the absorbance of $0.96 \mathrm{ng}$ As(III) in a $20 \mu$ injection showed that all amounts in the range $20-50 \mu \mathrm{g}$ had the same large absorbances. Hence, $20 \mu \mathrm{g}$ of $\mathrm{Ni}^{2+}$ in $20 \mu \mathrm{l}$ was selected.

\section{Reduction condition used for $A s(V)$}

The effect of the amount of L-cysteine $(0.10-1.0 \mathrm{ml}$ of $1 \%(\mathrm{w} / \mathrm{v})$ in $\left.0.2 \% \mathrm{HNO}_{3}(\mathrm{v} / \mathrm{v})\right)$ and the reaction time $(0.5-1.5 \mathrm{~h})$ on the reaction of $\mathrm{As}(\mathrm{V})(100 \mathrm{ng})$ to As(III) was studied. The results indicated that when the amount of L-cysteine was not sufficient $(<0.5 \mathrm{ml}$ of $1 \%(\mathrm{w} / \mathrm{v}))$ or the reaction time was not long enough $(<1$ $\mathrm{h})$, the reduction of $\mathrm{As}(\mathrm{V})$ to $\mathrm{As}(\mathrm{III})$ was incomplete. Since five $\mathrm{C}_{18}$ cartridges in series were required to obtain satisfactory recoveries for $100 \mathrm{ng}$ of $\mathrm{As}(\mathrm{V})$, we did not attempt to reduce larger amounts than this.

Calibration graphs, method detection limits (MDL), and accuracy tests for $A s(I I I)$ and $A s(V)$ in water

Following the proposed method, a typical calibration graph for $\mathrm{As}(\mathrm{III})$ was $y=0.0234 x-0.0017$ with a linear range of 12.5 - $200 \mathrm{ng} \mathrm{As}(\mathrm{III})$ and a correlation coefficient of 0.9995. The MDL for As(III) and As(V) were determined as the concentration corresponding to threetimes the standard deviation of twelve replicates using $20 \mu \mathrm{l}$ of a mixture containing $\mathrm{Ni}^{2+}$ and methanol obtained from the first $\mathrm{C}_{18}$ cartridge concentrated from a $25 \mathrm{ml}$ aqueous solution containing $0.5 \mu \mathrm{g} / \mathrm{l}$ of $\mathrm{As}(\mathrm{III})$ and $\operatorname{As}(\mathrm{V})$, respectively. The MDL $(3 \sigma)$ from the mean of six determinations were found to be $0.11 \pm 0.01 \mu \mathrm{g} / \mathrm{l}$ and $0.15 \pm 0.02 \mu \mathrm{g} / 1$ for $\mathrm{As}(\mathrm{III})$ and $\mathrm{As}(\mathrm{V})$, respectively, for a 25-ml aqueous solution, or an amount of $2.8 \mathrm{ng}$ As(III) and $3.8 \mathrm{ng} \mathrm{As}(\mathrm{V})$. Although the MDL values of $\mathrm{As}(\mathrm{III})$ and $\mathrm{As}(\mathrm{V})$ obtained in this work were higher than those $\left(0.001 \mu \mathrm{g} / 1^{11,12}, 0.011 \mu \mathrm{g} / \mathrm{l}^{13}\right.$ and $0.012 \mu \mathrm{g} / \mathrm{l}^{14}$ for $\mathrm{As}(\mathrm{III}) ; 0.010 \mu \mathrm{g} / \mathrm{l}^{11}, 0.018 \mu \mathrm{g} / \mathrm{l}^{13}$ and $0.062 \mu \mathrm{g} / \mathrm{1}^{14}$ for $\mathrm{As}(\mathrm{V}))$ reported elsewhere, those values might still be useful in practice for the maximum allowable contamination of $10 \mu \mathrm{g} / \mathrm{l}$ in drinking water.

The accuracies of the proposed method were checked by testing a QC sample $\left(\mathrm{As}_{2} \mathrm{O}_{3}\right.$, Strem Chemical Inc.) for As(III); a QC sample (wastewater, HPS\#290608) and the certified synthetic water (SRM 1643d) for As(V). The results of $97.6-99.3 \%$ were obtained, as listed in Table 3. The \%RSD at $100 \mathrm{ng}$ of As(III) and As(V) were within $4.0 \%$ and $2.5 \%$, respectively $(n=3)$.

\section{Effect of foreign ions on As(III) recovery}

For a $25 \mathrm{ml}$ aqueous solution containing $4.00 \mu \mathrm{g} / \mathrm{l}$ of As(III), the effects of $\mathrm{Ca}^{2+}, \mathrm{Mg}^{2+}, \mathrm{Fe}^{2+}, \mathrm{Mn}^{2+}, \mathrm{Na}^{+}$, and $\mathrm{Cl}^{-}$on the absorbance of arsenic could be tolerable up to $50,400,0.50,200,900$, and $1400 \mathrm{mg} / \mathrm{l}$ with 99,98 , $97,98,95$, and $95 \%$ recoveries, respectively.

\section{Determination of $A s(I I I)$ and $A s(V)$ in drinking water}

The concentrations of $\mathrm{As}(\mathrm{III})$ and $\mathrm{As}(\mathrm{V})$ in Tunghai groundwater, softened-distilled water, and pure water were determined by the proposed method and were
Table 3 Accuracy tests for $\mathrm{As}(\mathrm{III})$ and $\mathrm{As}(\mathrm{V})$ in drinking water

\begin{tabular}{cccc}
\hline \multirow{2}{*}{ Species } & \multicolumn{2}{c}{ Amount of As/ng } & \\
\cline { 2 - 3 } & Prepared & \multicolumn{1}{c}{ Found $^{\mathrm{d}}$} & \\
\hline \multirow{2}{*}{ As(III) } & $50.0^{\mathrm{a}}$ & $48.8 \pm 1.2$ & $97.6 \pm 2.5$ \\
& $100^{\mathrm{a}}$ & $98.9 \pm 2.8$ & $98.9 \pm 2.8$ \\
& $200^{\mathrm{a}}$ & $195.8 \pm 7.8$ & $97.9 \pm 4.0$ \\
As(V) & $100^{\mathrm{b}}$ & $98.4 \pm 2.5$ & $98.4 \pm 2.5$ \\
& $50.5 \pm 0.7^{\mathrm{c}}$ & $50.2 \pm 0.4$ & $99.3 \pm 0.8$ \\
& $100.8 \pm 1.3^{\mathrm{c}}$ & $99.2 \pm 0.5$ & $98.5 \pm 0.5$ \\
\hline
\end{tabular}

a. Prepared from a QC sample $\left(\mathrm{As}_{2} \mathrm{O}_{3}\right.$, Strem Chemical Inc.). b, c. Prepared from a QC sample (wastewater, HPS\#290608) and the standard reference material (SRM 1643d, synthetic water), respectively.

d. Mean of three determinations with standard deviation.

found as N.D. $(<0.11 \mu \mathrm{g} / \mathrm{l}$ for As(III) and $<0.15 \mu \mathrm{g} / \mathrm{l}$ for $\mathrm{As}(\mathrm{V}))$ both in acidified samples and an unacidified Tunghai groundwater $(20 \mathrm{ml})$. After spiking As(III) (50.0 or $100 \mathrm{ng}$ ) and $\mathrm{As}(\mathrm{V})(100 \mathrm{ng})$ to samples, respectively, the average recoveries from triplicates were 98.5 - $102 \%$ for the unacidified sample (with \%RSD within $2.8 \%$ ) and $95.7-101 \%$ for the acidified samples (with \% RSD within 4.3\%).

Feasibility of collecting As(III) vapor by use of an absorbing solution

The absorbing efficiencies in impinger \#1 for As(III) vapor simulated from $100 \mathrm{ng}$ of As(III) in methanol ranged from 34.2 to $60.8 \%$ when the IR irradiation time was varied from 0.5 to $4 \mathrm{~h}$ at an air flow rate of 250 $\mathrm{ml} / \mathrm{min}$ (except for one at $350 \mathrm{ml} / \mathrm{min}$ ) as listed in Table 4. The results indicated that an IR irradiation time of at least $2 \mathrm{~h}$ was required to vaporize most of the $\mathrm{As}_{2} \mathrm{O}_{3}$ and to obtain a $60 \%$ collection efficiency in impinger \#1; however, the residue portion found from the glass chamber was $11-13 \%$ and the amount found in impinger \#2 was N.D. (<2.8 ng As(III)). The total recovery of $\mathrm{As}(\mathrm{III})$ by this generating technique was only about $72 \%$. This might be because $\mathrm{As}_{2} \mathrm{O}_{3}$ has a high melting point $\left(275^{\circ} \mathrm{C}\right)$ and a high sublimation point $\left(313^{\circ} \mathrm{C}\right) ;^{7}$ therefore some portion of the $\mathrm{As}_{2} \mathrm{O}_{3}$ still remained on the glass chamber and was not evaporated under the IR irradiation (about $130^{\circ} \mathrm{C}$ ) nor extracted by a fresh absorbing solution $(15 \mathrm{ml})$. The $\%$ RSD for collecting As(III) vapor in impinger \#1 with an IR irradiation for $2 \mathrm{~h}$ was $4.5 \%$ from a triplicate. From the result of absorbing in impinger \#1, the collection of As(III) vapor in air might be feasible.

\section{Determination of As(III) contents from air samples}

Three pairs of air samples were collected from inside our laboratory (120 1), outside our laboratory (120 1), and on the farm of Tunghai University (1201), which is about $400 \mathrm{~m}$ away from the incinerator of Taichung Veteran's Hospital, respectively, together with a corresponding blank. The obtained results were N.D. 
Table 4 Collection efficiency for simulated As(III) vapor

\begin{tabular}{|c|c|c|c|c|c|c|}
\hline \multicolumn{4}{|c|}{ Amount of As(III)/ng } & \multirow{3}{*}{$\begin{array}{c}\text { Total } \\
\text { recovery, \% }\end{array}$} & \multirow{3}{*}{$\begin{array}{l}\text { IR irradiation } \\
\text { time }^{\mathrm{b}} / \mathrm{h}\end{array}$} & \multirow{3}{*}{$\begin{array}{l}\text { Volume of } \\
\text { air/l }\end{array}$} \\
\hline \multirow{2}{*}{ Introduced } & \multicolumn{3}{|c|}{ Found $^{\mathrm{a}}$} & & & \\
\hline & Imp.\#1 & Imp.\#2 & Chamber & & & \\
\hline 100 & $34.2 \pm 1.6$ & N.D. ${ }^{c}$ & $35.2 \pm 1.1$ & 69.4 & 0.5 & $30^{\mathrm{d}}$ \\
\hline 100 & $44.2 \pm 2.2$ & N.D. & $26.7 \pm 1.8$ & 70.9 & 1 & $30^{\mathrm{d}}$ \\
\hline 100 & $60.3 \pm 2.7$ & N.D. & $11.0 \pm 2.6$ & 71.3 & 2 & $30^{\mathrm{d}}$ \\
\hline 100 & $60.5 \pm 2.0$ & N.D. & $11.7 \pm 2.3$ & 72.2 & 2 & $42^{\mathrm{f}}$ \\
\hline 100 & $60.8 \pm 1.8$ & N.D. & $11.2 \pm 2.5$ & 72.0 & 4 & $60^{\mathrm{e}}$ \\
\hline
\end{tabular}

a. Mean of triplicates with standard deviation. b. IR lamp further irradiation time after 10 min. c. N.D. <2.8 ng. d, e and f. Air flow rate at $250 \mathrm{ml} / \mathrm{min}$ for $2 \mathrm{~h}$; for $4 \mathrm{~h}$; and $350 \mathrm{ml} / \mathrm{min}$ for $2 \mathrm{~h}$, respectively.

(which is $<2.8 \mathrm{ng}$ of $\mathrm{As}(\mathrm{III})$ for an air volume of 1201 , or about $<23 \mathrm{ng} / \mathrm{m}^{3}$ ).

The authors thank the National Science Council of the Republic of China for financial support (NSC 86-2113-M-029007).

\section{References}

1. W. P. Tseng, H. M. Chu, S. W. How, J. M. Fong, C. S. Lin and S. Yeh, J. Nat. Cancer Inst., 40, 453 (1968).

2. C. J. Chen, Y. Chuang, T. M. Lin and H. T. Wu, Cancer Res., 45, 5895 (1985).

3. A. H. Smith, H. M. Duggan, R. Wood, M. J. Kosnett and M. T. Smith, Environ. Health Perspect., 97, 259 (1992).

4. S. L. Chen, S. R. Dzeng, M. H. Yang, K. H. Chiu, G. M. Shieh and C. M. Wai, Environ. Sci. Technol., 28, 877 (1994).

5. Y. C. Chen, H. C. Wang, S. Y. Cheng, C. H .Yen and M. S. Kuo, J. Environ. Prot. Soc. [R.O.C.], 19, 14 (1996).

6. F. W. Pontius, J. AWWA, Feb., 48 (1995).

7. NIOSH method 7901, “Arsenic Trioxide, as As", 1994.

8. M. Sperling, X. Yin and B. Welz, Spectrochim. Acta, 46B, 1789 (1991).

9. B. Welz and M. Sucmanova, Analyst [London], 118, 1417 (1993).

10. T. R. Rude and H. Puchelt, Fresenius' J. Anal. Chem., 350, 44 (1994).
11. M. Hasegawa, Y. Sohrin, M. Matsui, M. Hojo and M. Kawashima, Anal. Chem., 66, 3247 (1994).

12. W. M. Mok and C. M. Wai, Anal. Chem., 59, 233 (1987).

13. C. J. Hwang and S. J. Jiang, Anal. Chim. Acta, 289, 205 (1994).

14. ML. Magnuson, N. T. Creed and C. A. Brockhoff, J. Anal. At. Spectrom., 11, 893 (1996).

15. H. V. Aposhian, C. H. Tadlock and T. E. Moon, Toxicol. Appl. Pharmacol., 61, 385 (1981).

16. D. F. Moore, C. A. Ocallaghan, G. Berlyne, C. S. Ogg, H. A. Davies, I. M. House and J. A. Henry, J. Neurol. Neurosur. Psych., 57, 1133 (1994).

17. R. D. Ediger, At. Absorpt. Newsl., 14, 127 (1995).

18. D. C. Manning and W. Slavin, Appl. Spectrosc., 37, 1 (1983).

19. W. L. Jolly, "The Principles of Inorganic Chemistry", p. 199, McGraw-Hill, New York, 1976.

20. H. Chen, I. D. Brindle and X. C. Le, Anal. Chem., 64, 667 (1992).

21. Y. L. Feng and J. P. Cao, Anal. Chim. Acta, 293, 211 (1994).

22. H. C. Wang, Y. C. Hwang, C. J. Hsieh and M. S. Kuo, Anal. Sci., 14, 983 (1998).

23. L. Stryer, "Biochemistry", 2nd ed., pp. 15 - 18, W. H. Freeman and Company, San Francisco, 1981.

(Received November 9, 1998) (Accepted April 22, 1999) 